\title{
PIM2 and NF-K $\beta$ gene expression in a sample of AML and ALL Egyptian patients and its relevance to response to treatment
}

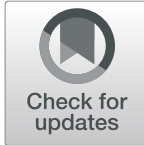

Shymaa Kamal El Din Abed El Rahman¹, Sanaa Sayed Abd Elshafy', Mohamed Samra ${ }^{2}$, Hala Mohammed Ali ${ }^{3}$ and Rabab Afifi Mohamed ${ }^{1 *}$ (D)

\begin{abstract}
Background: The relation between PIM2 and the transcriptional factor NF $\mathrm{k} \beta$ have been controversial in literature. The significance of PIM2 and NF-K $\beta$ genes expression on the incidence of acute leukemia (AML and ALL) and its relevance to the response rate was evaluated. Sixty de novo acute leukemia patients were stratified in 2 groups: 30 acute myeloid leukemia (AML) and 30 acute lymphoblastic leukemia (ALL) patients and compared to 30 sex- and age-matched controls. The expression level of PIM2 and NF K $\beta$ genes was measured using quantitative real-time polymerase chain reaction (QRT-PCR). The patients were followed with clinical examination and complete blood counts.
\end{abstract}

Results: The expression level of PIM2 gene was significantly higher in AML patients $(P<0.001)$ compared to the control group. The mean expression level of $N F \kappa \beta$ gene was significantly high in AML and ALL patients compared to the healthy control group ( $P=0.037$ and $P<0.001$; respectively). The overall survival in AML patients was higher in $N F K \beta$ gene low expressers compared to high expressers $(P=0.047)$. The number of AML patients who achieved complete remission was significantly higher in PIM2 gene low expressers in comparison to PIM2 gene high expressers $(P=0.042)$.

Conclusion: PIM2 and NF K $\beta$ genes might have a role in the pathogenesis of acute leukemia, poor overall survival, and failure of response to induction therapy.

Keywords: NF K $\beta$, PIM2, Acute leukemia, QRT-PCR, Expression, Response

\section{Background}

Acute myeloid leukemia (AML) - the most common type of acute leukemia in adults-is an aggressive disease, characterized by the propagation of clonal neoplastic myeloid hematopoietic precursors with impairment of normal hematopoiesis [1]. The clinical outcome in AML ranges from death within a few days of starting treatment to likely cure. Resistance to treatment represents the main reason patients are not cured. This manifests as relapse after remission [2].

\footnotetext{
* Correspondence: rabab.eltememy@gmail.com

${ }^{1}$ Clinical and Chemical Pathology Department, Faculty of Medicine, Beni-Suef University, Beni-Suef 62511, Egypt

Full list of author information is available at the end of the article
}

Acute lymphoblastic leukemia (ALL) encompasses a group of lymphoid neoplasms. These disorders are classified by the WHO as B-lymphoblastic or Tlymphoblastic leukemia/lymphoma. These leukemic processes of these neoplasms is associated with the involvement of the peripheral blood, bone marrow, or may be limited to the infiltration of tissues with absent or limited (less than 20\%) bone marrow association [3].

The PIM kinases are serine/threonine kinases which function as proto-oncogenes and play a role in cell survival, through activation of genes involved in cell proliferation [4]. The three isoforms of the PIM kinases (PIM1, PIM2, and PIM3) play a major role in tumorigenesis [5].

\section{Springer Open}

(๑) The Author(s). 2021 Open Access This article is licensed under a Creative Commons Attribution 4.0 International License, which permits use, sharing, adaptation, distribution and reproduction in any medium or format, as long as you give appropriate credit to the original author(s) and the source, provide a link to the Creative Commons licence, and indicate if changes were made. The images or other third party material in this article are included in the article's Creative Commons licence, unless indicated otherwise in a credit line to the material. If material is not included in the article's Creative Commons licence and your intended use is not permitted by statutory regulation or exceeds the permitted use, you will need to obtain permission directly from the copyright holder. To view a copy of this licence, visit http://creativecommons.org/licenses/by/4.0/. 
The upregulation PIM2 gene, in variety of cancers, serves an important role in regulating signal transduction cascades involved in the promotion of cell survival and proliferation [6]. In addition, PIM2 gene expression is involved in the reduction of the cells' sensitivity to various apoptotic stimuli and the negative response to the withdrawal of growth factor [7].

P65 (RelA), RelB, c-Rel, p105/p50, and p100/p52 are members of the NF- $\mathrm{kB}$ family of transcription factors. They form homo- or hetero-dimers and are involved in the regulation of multiple physiological and pathological processes. In resting cells, the members of the NF- $\mathrm{kB}$ family tend to localize in the cytoplasm associated with IKBs which is a family of inhibitor proteins. When stimulated, NF $\kappa B$ are released from their inhibitor proteins, translocate into the nucleus, and bind to its target genes and hence, regulates their transcription [8].

The relationship between PIM2 and NF $\kappa B$ has been controversial in literature, with some studies placing PIM2 upstream of NF $\kappa \mathrm{B}$ and other studies the reverse [9]. In the current case control study, we evaluated the significance of PIM2 and $N F-\kappa B$ genes expression level on the incidence of acute leukemia (AML and ALL) and its value in treatment response rate.

\section{Methods \\ Patients}

The present study was conducted on 60 de novo acute leukemia patients. The patients were recruited from the outpatient clinic of the National Cancer Institute (NCI). We divided the patients into 2 groups: the first group consisted of 30 de novo AML patients and the second group consisted of 30 de novo ALL patients. AML patients consisted of 18 males and 12 females while ALL patients' group consisted of 12 males and 18 females. The ages of AML patients ranged between 17 and 70 years $(33.7 \pm 14.2)$, while the ages of ALL patients ranged between 19 and 55 years (28.9 \pm 8.47$)$. Thirty matched healthy subjects were recruited as controls. The control group consisted of 15 males and 15 females and their ages ranged from 17 to 53 years $(29.23 \pm 8.47 \mathrm{SD})$.

\section{Criteria of inclusion and exclusion}

De novo acute leukemia patients with different FAB subtypes were enrolled in the study. AML patients with normal karyotypes were selected using conventional cytogenetic analysis, which was performed at the time of diagnosis on bone marrow aspirate. Twenty or more metaphase cells were examined to ensure normal karyotypes (CN-AML) [10]. We excluded therapy related acute leukemia patients.

\section{Ethical approval and consent to participate}

The study was conducted after the approval of the Institutional Review Board of the National Cancer institute (approval date 3 March 2015; approval no. 2010014035.3), which conforms with the Code of Ethics of the World Medical Association (Declaration of Helsinki), printed in the British Medical Journal (18 July 1964).We described the aim of this research to subjects' parents or responsible relative shared in this research before enrollment and they gave written consent.

\section{Laboratory and clinical criteria}

The diagnosis of acute leukemia was based on full history taking and thorough clinical examination. Laboratory diagnosis of acute leukemia was based on morphologic findings: cytochemical stains, immunophenotyping by flowcytometry, and molecular studies-in accordance with the WHO classification [11, 12]. Routine laboratory examinations included liver and kidney function tests.

\section{Treatment protocols}

The treatment protocol of AML patients consisted of the standard " $3+7$ " induction therapy protocol: doxorubicin ( $45 \mathrm{mg} / \mathrm{m}^{2} /$ day) for 3 days and cytarabine $\left(100 \mathrm{mg} / \mathrm{m}^{2} /\right.$ day) as a continuous $24 \mathrm{~h}$ infusion for 7 days [13]. Consolidation consisted of three to four courses of cytosine arabinoside $\left(3 \mathrm{~g} / \mathrm{m}^{2}\right.$ every $12 \mathrm{~h}$ on days 1,3 , and 5 ; total of $18 \mathrm{~g} / \mathrm{m}^{2}$ ). The treatment protocol of ALL patients consisted of the following: induction with hyper CVAD (cyclophosamide 300 $\mathrm{mg} / \mathrm{m}^{2}$ IV every $12 \mathrm{~h}, 6$ doses, days 1-3 Mesna 600 $\mathrm{mg} / \mathrm{m}^{2} /$ day CIVI over $24 \mathrm{~h}$, days $1-3$ (optional)). Doxorubicin $50 \mathrm{mg} / \mathrm{m}^{2}$ CIVI over 24 h day 4 , vincristine $2 \mathrm{mg}$ IV day 4 and 11. Dexamethasone $40 \mathrm{mg}$ PO 1-4 and 11-14. Central nervous system prophylaxis consisted of cranial irradiations and intrathecal chemotherapy [14]. Bone marrow examination on day 28 was used to assess the response to treatment. Follow-up was done once after 3 months with clinical examination and complete blood counts. Complete remission (CR) was established as follows: granulocyte count at least $1.5 \times 10^{9} / \mathrm{L}$, platelet count at least 100 $\times 10^{9} / \mathrm{L}$, absence of peripheral blood blasts, BM cellularity of at least $20 \%$ with maturation of all cell lines and less than 5\% blasts, and no extramedullary leukemia. The appearance of peripheral blood blasts, more than $5 \%$ in the bone marrow or presence of extramedullary manifestations after $\mathrm{CR}$, was used to determine the presence of relapse. The remission status was assessed after the completion of the induction. 


\section{RT-PCR expression analysis of PIM2 and NF-KB genes}

Three milliliters of blood was withdrawn from the patients and the control group in a preservative free-EDTA vacutainer tube. RNA extraction was performed in accordance to the manufacturer protocol using RNA isolation kit (QIAamp • RNA Blood Mini Kits). Reversed transcription (cDNA) was performed in accordance to the manufacturer protocol, high capacity cDNA reverse transcription kit (Applied Biosystems, USA) was used, using T-personal thermal cycler (Biometra). Quantitaive RT-PCR for PIM2 and NF- $\kappa B$ genes was done using Applied Biosystems Step one ${ }^{\mathrm{TM}}$ Instrument (USA) in accordance to the manufacturer protocol, using Taqman ${ }^{\circ}$ gene expression assays Hs00179139_m1 and Hs00231653_m1 (Applied Biosystems). The expression levels were normalized to the geometric mean using the house keeping gene beta-glucorondinase (GUS) (Taqman Gene Expression Assay Hs99999908_1) [15]. The optimized cycling conditions for PCR were as follows: 50 ${ }^{\circ} \mathrm{C}$ for $2 \mathrm{~min}, 95^{\circ} \mathrm{C}$ for $10 \mathrm{~min}$, then 40 cycles each consisted of $95{ }^{\circ} \mathrm{C}$ for $15 \mathrm{~s}$ and $60{ }^{\circ} \mathrm{C}$ for $1 \mathrm{~min}$. The interpretations were performed by using the comparative $C_{\mathrm{t}}$ method for relative quantitation (RQ) which is expressed as $2^{-\Delta \Delta \mathbf{C t}}$.

\section{Survival analysis}

As regards the survival analysis, we calculated the overall survival (OS) from D0 till the date of death or the last follow-up date. At the end of the study, the number of patients was 58 as 2 acute lymphoblastic leukemia patients refused treatment. The calculation of disease-free survival was done only for patients who reached CR, which is assessed form starting treatment until date of relapse, disease progression, death (irrespective of the cause), or last follow-up [16].

\section{Statistical analysis}

IBM@ Statistics version 22 (IBM@Corp., Armonk, NY, USA) was used for the performance of statistical analysis. Mean and standard deviation or median and range were used to express the numerical data as appropriate. Frequency and percentage were used to express the qualitative data. The relationship between qualitative variables was examined by Fisher's exact test. MannWhitney test was performed for comparison between 2 groups. Kruskal-Wallis test (non-parametric ANOVA) was used for comparison between 3 groups then pairwise comparison was done by post hoc test based on Kruskal-Wallis distribution. Spearman-rho method was used for correlation between numerical variables. Kaplan-Meier method was used for survival analysis and the log-rank test was used for the comparison between the two survival curves. All tests were two-tailed. A $P$ value $<0.05$ was considered significant.

\section{Results}

The current study was conducted on 60 de novo adult acute leukemia patients (30 AML and 30 ALL patients), the cases were compared to 30 age- and sex-matched healthy control subjects. The descriptive data are summarized in Table 1.

\section{Expression of PIM2 and NF- $\kappa \beta$ genes in acute leukemia patients}

The expression level PIM2 and $N F-\kappa \beta$ genes were detected using RT-PCR in both AML and ALL patient groups. The mean level of PIM2 gene expression was significantly higher in the AML patients compared its expression level in the healthy control group $(P<0.001)$. The mean level of expression of PIM2 gene was higher in ALL patients in comparison to the control group, and the difference between the groups was nearly statistically significant $(P=0.051)$. The mean level of expression of $N F \kappa \beta$ was significantly higher in AML and ALL groups compared to the control group $(P=0.0371, P<0.001$; respectively) (Table 2).

The association between the expression level of PIM2 and $N F-\kappa \beta$ genes and FAB classification of both AML and ALL subgroups did not reveal a significant

Table 1 Demographic, laboratory and clinical data of acute leukemia patients (AML and ALL) and control group

\begin{tabular}{|c|c|c|c|}
\hline Parameter & AML No. (\%) & ALL No. (\%) & Controls \\
\hline \multicolumn{4}{|l|}{ Gender } \\
\hline Male & $18(60 \%)$ & $12(40 \%)$ & $15(50 \%)$ \\
\hline Female & $12(40 \%)$ & $18(60 \%)$ & $15(50 \%)$ \\
\hline \multicolumn{4}{|l|}{ Age At diagnosis } \\
\hline Median & 30.0 & 27.0 & 31.0 \\
\hline Range & $17.0-70.0$ & $19.30-55.0$ & $18.0-65.0$ \\
\hline \multicolumn{4}{|l|}{ Lab. findings } \\
\hline $\mathrm{TLC} \times 10^{3} / \mu \mathrm{L}$ & $111.5 \pm 138.06^{a}$ & $137.36 \pm 190.21^{a}$ & $7.11 \pm 1.72^{a}$ \\
\hline Hemoglobin g/dl & $7 \pm 1.7^{a}$ & $8.4 \pm 1.6^{a}$ & $11.7 \pm 1.0^{\mathrm{a}}$ \\
\hline Platelet $\times 10^{3} / \mu \mathrm{L}$ & $75.2 \pm 81.3^{a}$ & $59.3 \pm 62.1^{a}$ & $306.3 \pm 78.5^{a}$ \\
\hline Blasts $^{b}$ & $62.6 \pm 29.3^{a}$ & $76.5 \pm 26.7^{\mathrm{a}}$ & $N A^{d}$ \\
\hline \multicolumn{4}{|l|}{ Clinical data (no. \%) } \\
\hline Hepatomegaly & $15(50 \%)$ & $16(53.3 \%)$ & $N A^{d}$ \\
\hline Splenomegaly & $13(43.3 \%)$ & 17 (56.7\%) & $N A^{d}$ \\
\hline Lymphadenopathy & $7(23.3 \%)$ & $26(86.7 \%)$ & $N A^{d}$ \\
\hline \multicolumn{4}{|l|}{ Response rate (no. \%) } \\
\hline$C R^{C}$ & $16(53.3 \%)$ & 19 (63.3\%) & $N A^{d}$ \\
\hline$N C R^{c \& e}$ & $14(46.6 \%)$ & $9(30 \%)$ & $N A^{d}$ \\
\hline
\end{tabular}

${ }^{\mathrm{a}}$ Mean \pm SD (range)

${ }^{b}$ Bone marrow blasts\%

${ }^{c} C R$ complete remission, $N C R$ no complete remission (relapse and death) ${ }^{\mathrm{d}} \mathrm{NA}$ not applicable

${ }^{e} 2$ out of $30 \mathrm{ALL}$ patients refused treatment so the number of NCR reflects the number of deaths only 
Table 2 Expression of NF $k \beta$ and PIM2 genes in AL patients and the controls

\begin{tabular}{cllll}
\hline & Control group & AML group & ALL group & $P$ value \\
\hline PIM2 & & & & \\
Mean \pm SD & $0.164 \pm 0.107$ & $8.220 \pm 12.902$ & $6.194 \pm 21.071$ & ${ }^{*} P 1<0.001$ \\
Median & 0.160 & 1.389 & 0.303 & ${ }^{*} P 2=0.510$ \\
Range & $0.27-0.34$ & $0.13-53.04$ & $0.004-83.64$ & \\
NF K $\beta$ & & & & \\
Mean $\pm S D$ & $0.446 \pm 0.297$ & $0.957 \pm 0.459$ & $2.697 \pm 2.326$ & ${ }^{*} P 3=0.009$ \\
Median & 0.440 & 1.019 & 1.988 & ${ }^{*} P 4<0.001$ \\
Range & $0.55-0.90$ & $0.20-2.20$ & $0.12-8.63$ & \\
\hline
\end{tabular}

P1, AML/controls; P2, ALL/controls; P3, AML/controls; P4, ALL/controls

${ }^{*} P$ values are significant if $<0.05$

difference (Figs. 1 and 2) .The AML and ALL patients were further sub-divided according to the presence or absence of hepatomegaly, splenomegaly, and lymphadenopathy. The mean expression level of PIM2 gene was significantly higher in AML and ALL patients with hepatomegaly compared to patients without hepatomegaly ( $P=0.037, P=0.038$, respectively). The mean level of expression of $N F-\kappa \beta$ gene was significantly higher in ALL patients with hepatomegaly $(P=0.022)$, while its expression level was not related to the presence of hepatomegaly in patients with AML. On assessment of the mean expression level of PIM2 gene in acute leukemia patients with splenomegaly in comparison to patients with no splenomegaly, a significant elevation in the level of PIM2 gene was detected in ALL patients with splenomegaly $(P=0.007)$. The mean expression level of PIM2 gene was elevated in AML patients with splenomegaly but the level of expression was not significant $(P=0.072)$. We did not detect a significant elevation in the expression level of $N F-\kappa \beta$ gene in AL patients with splenomegaly in comparison to AML and ALL patients with no splenomegaly. Similarly, the level of expression of PIM2 and NF-K $\beta$

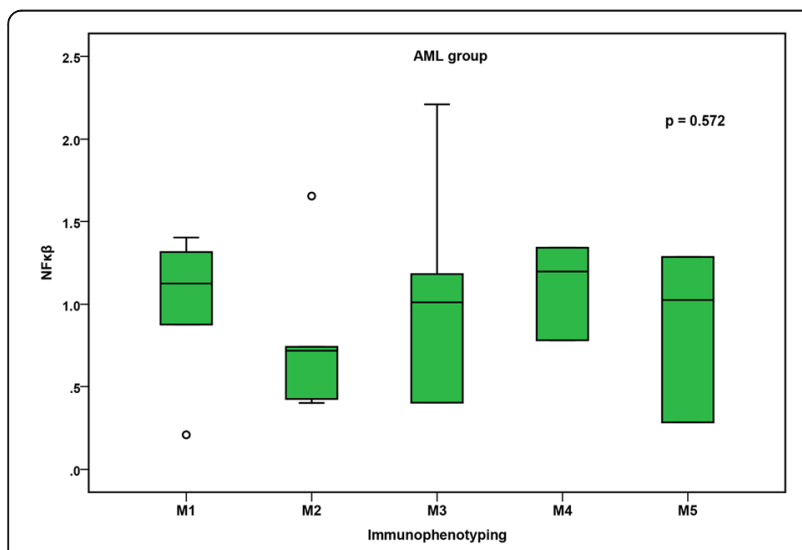

Fig. 1 Association of NF-K $\beta$ gene expression with immunophenotyping in AML group

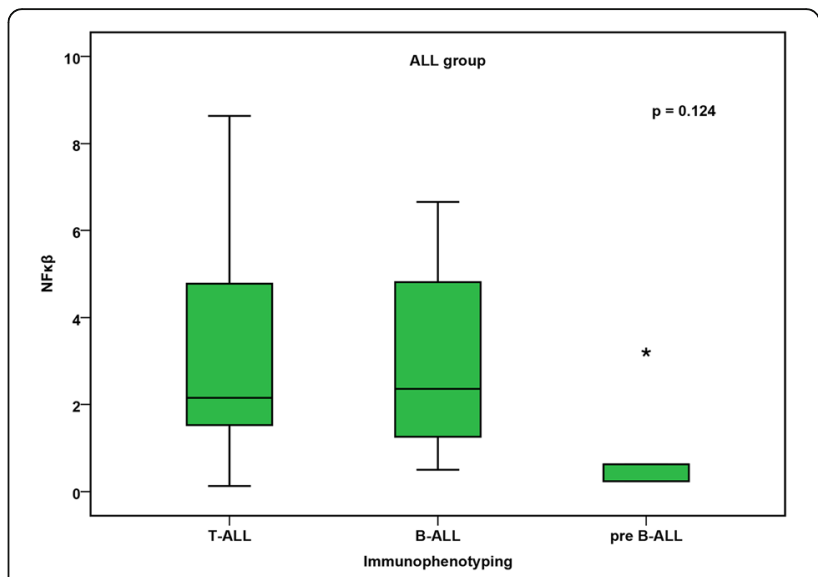

Fig. 2 Association of NF-K $\beta$ gene expression with immunophenotyping in ALL group

genes was not significantly elevated in AML and ALL patients with lymphadenopathy compared to patients with no lymphadenopathy (Table 3 ).

\section{Correlative studies}

A weak positive correlation was detected between expression level of PIM2 and NF- $\kappa \beta$ genes in AML $(r=$ 0.364, $P=0.048$ ) (Fig. 3). No correlation was detected between PIM2 and NF $\kappa \beta$ genes expression level in ALL patients $(r=0.189, P=0.316)$.

\section{Survival analysis}

The median expression level of NF- $\kappa \beta$ and PIM2 genes in AML and ALL patients were calculated. The median expression level of PIM2 in AML patients was 1.389 while in ALL patients it was 0.303 (Table 2). The median expression level of $N F-K \beta$ gene in AML patients was 1.019 while in ALL patients it was 1.988 (Table 2). The median expression level was taken to discriminate between high and low expressers of PIM2 and NF- $\kappa \beta$ genes in AML and ALL patients. The median level of expression was used in the calculation of the survival analysis which included the overall survival and the disease-free survival. Regarding the OS in AML patients' group, a significant difference was detected, as the cumulative survival at 3 months interval was higher in $N F-\kappa \beta$ gene low expressers compared to high expressers $(P=0.047)$ (Table 3$)$. There was no significant difference detected regarding the cumulative survival between PIM2 gene low and high expressers in AML patients' group (Table 4). In ALL patients, no significant difference was detected in the cumulative survival at 3 months interval regarding the high or low expressers of PIM2 and NF- $\kappa \beta$ genes (Table 4).

As regards disease-free survival, a significant difference was detected in PIM2 gene low expressers compared to high expressers, as regards the percentage of AML patients who achieved complete remission compared to 
Table 3 Assocition of lymphadenopathy with the expression of NF $\mathrm{K} \beta$ and PIM2 genes in AML and ALL patients

\begin{tabular}{lll}
\hline & Lymphadenopathy $\boldsymbol{N}(\%)$ & No lymphadenopath $\boldsymbol{N}$ (\%) \\
\hline PIM2 gene expression (in AML patients) & No. $7(23.3 \%)$ & No. 23 (76.7\%) \\
Mean \pm SD & $0.836 \pm 4.226$ & $9.744 \pm 14.288$ \\
Range & $0.609-12.535$ & $0.131-53.040$ \\
NF-K $\beta$ expression (in AML patients) & & \\
Mean $\pm S D$ & $0.836 \pm 0.412$ & $0.995 \pm 0.457$ \\
Range & $0.402-1.284$ & $0.207-2.208$ \\
PIM gene expression (in ALL patients) & No. $26(86.7 \%)$ & No. $4(13.3 \%)$ \\
Mean $\pm S D$ & $7.090 \pm 22.555$ & $0.369 \pm 0.195^{\&}$ \\
Range & $0.004-83.644$ & $0.127-0.605$ \\
NF-K $\beta$ gene expression (in ALL patients) & & \\
Mean $\pm S D$ & $2.437 \pm 2.198$ & $4.384 \pm 2.769^{\&}$ \\
Range & $0.128-8.630$ & $1.024-6.655$ \\
\hline
\end{tabular}

$N$ number of patients

${ }^{*} P$ values are significant if $<0.005$

${ }^{\circledR}$ No $P$ value duo to small number of patients

AML patients who did not show a response to induction $(P=0.042)$ (Table 5). We did not detect a significant difference between $N F-\kappa \beta$ gene high or low expressers as regards the cumulative 3 months survival in the AML patients' group. Similarly, no significant difference was detected between PIM2 and NF- $\kappa \beta$ genes high expressers and low expressers as regards cumulative 3 months survival.

\section{Discussion}

Failure of induction of apoptosis is an important phenomenon resulting in the accumulation of neoplastic cells in leukemic patients [17]. PIM2 which is a member of PIM kinases (serine/threonine kinases) has three isoforms, and the shorter one (PIM2 [34KDal]) has the strongest function in enhancing cell survival [18]. NF $\kappa \beta$, one of the main regulators of cell survival and differentiation, cause the expression of certain proteins that result

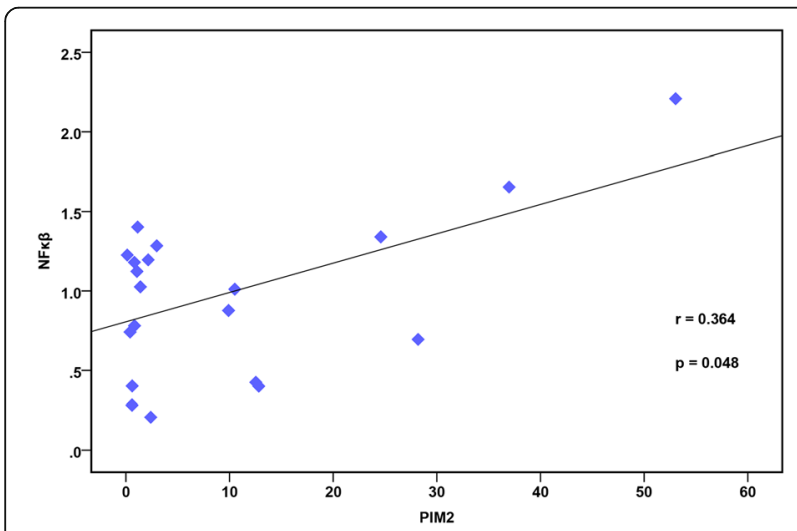

Fig. 3 Correlation between PIM2 and NF-k $\beta$ genes expression level in AML patients in the survival of tumor cells through the inhibition of apoptosis, resulting in cell invasiveness and chemotherapeutic resistance [19]. It was suggested that the action of PIM2 on cell proliferation might be related to NF- $\kappa \beta$ signaling [20].

Thus, in an attempt to further document the interrelation between NF- $\kappa \beta$ and PIM2 genes expression in acute leukemia, we set to investigate and evaluate their role in leukemogenesis in a sample of de novo AML and ALL Egyptian patients. Furthermore, we investigated their role in the disease progression and the response to therapy, represented by the OS and the DFS.

In the present study, a significant rise in the mean expression level of PIM2 was detected in AML patients in comparison to the control group $(P<0.001)$. As regards ALL patients, the expression level of PIM2 was higher in ALL patients compared to the control group; however, no significant difference was found between the groups $(P=0.051)$.

The results regarding the level of expression of PIM2 were consistent with the results of the study conducted by Kataryza et al. (2013) [17]. Similarly, Mizuki et al. observed a significant induction of PIM2 mRNA in AML samples. In addition, Tamburini et al. found that PIM2 gene was constitutively expressed in AML blasts in contrast to their rare expression in normal CD34+ hematopoietic progenitors [21, 22]. Furthermore, PIM2 gene expression was found to be increased in lymphoid malignancies compared to controls [23].

The increase in the expression level of PIM2 gene in hematological malignancies could be related to their role in cell survival and proliferation, as they are downstream effectors of important oncoproteins such as Ableson (ABL) and Janus Kinase 2 (JAK2) [24]. Furthermore, a 
Table 4 Overall survival of AML and ALL patients in relation to NF K $\beta$ and PIM2 median expression level

\begin{tabular}{|c|c|c|c|c|c|}
\hline & No. & No. of deaths & Cumulative survival at 3 months (\%) & Median survival (months) & $P$ value \\
\hline \multicolumn{6}{|l|}{ AML patients group } \\
\hline \multicolumn{6}{|c|}{ NF $\mathrm{k} \beta$ gene median expression } \\
\hline $1.019^{\text {low\$ }}$ & 15 & 1 & 93.3 & $----\%$ & $0.047^{*}$ \\
\hline $1.019^{\text {equal/high\# }}$ & 15 & 6 & 66.7 & 12.4 & \\
\hline \multicolumn{6}{|c|}{ PIM2 gene median expression } \\
\hline $1.389^{\text {low\$ }}$ & 14 & 3 & 85.7 & 12.4 & 0.872 \\
\hline $1.389^{\text {equal/high\# }}$ & 16 & 4 & 75.0 & --- & \\
\hline \multicolumn{6}{|l|}{ ALL patients group } \\
\hline \multicolumn{6}{|c|}{$\mathbf{N F} \mathbf{\kappa} \boldsymbol{\beta}$ gene median expression } \\
\hline $1.988^{\text {low\$ }}$ & 14 & 3 & 78.6 & ---- & 0.228 \\
\hline $1.988^{\text {equal/high\# }}$ & 14 & 6 & 60.0 & --- & \\
\hline \multicolumn{6}{|c|}{ PIM2 gene median expression } \\
\hline $0.303^{\text {low\$ }}$ & 14 & 3 & 64.3 & --- & 0.872 \\
\hline $0.303^{\text {equal/high\# }}$ & 14 & 4 & 71.4 & ---- & \\
\hline
\end{tabular}

previous study illustrated that inhibition of $C D K 2$ and $p R b$ expression through upregulating CDKNIA gene expression has resulted in the downregulation of PIM2 gene and the arrest of the cell cycle in the G0/G1 phase in lung cancer and hematopoietic malignancies which thus confirms its anti-apoptotic role [25].

On evaluating the mean level of expression of $N F$ $\kappa \beta$ gene in AML and ALL patients compared to the control group, the mean level of expression of $N F-\kappa \beta$ gene has shown a significant increase in both AML and ALL patients in comparison to the control group ( $P=0.009$ and $P<0.001$; respectively). These results are in accordance with the results of Katarzyna et al. and Kapleko-Slowik $[17,26]$. In a previous study performed by Guzman et al., detailed analysis of enriched AML stem cells, revealed the activation of $N F-\kappa \beta$ gene in leukemia stem cells (LSCs) population [27]. Moreover, Kordes et al. detected that $N F-\kappa \beta$

Table 5 Disease-free survival in AML and ALL patients in relation to PIM 2 and NF K $\beta$ median expression

\begin{tabular}{|c|c|c|c|c|c|}
\hline & No. & CR no. & Relapse or no. of deaths & Cumulative survival at 3 months $\%$ & $P$ value \\
\hline \multicolumn{6}{|l|}{ AML patients group } \\
\hline \multicolumn{6}{|c|}{$N F \mathrm{k} \beta$ gene median expression } \\
\hline $1.019^{\text {low }}$ & 15 & 10 & 5 & 56.0 & \multirow[t]{2}{*}{0.593} \\
\hline $1.019^{\text {equal/high\# }}$ & 15 & 6 & 9 & 53.3 & \\
\hline \multicolumn{6}{|c|}{ PIM2 gene median expression } \\
\hline $1.398^{\text {low\$ }}$ & 14 & 11 & 3 & 85.7 & \multirow[t]{2}{*}{$0.042^{*}$} \\
\hline $1.398^{\text {equal/high\# } 16}$ & 1 & 8 & 6 & 37.5 & \\
\hline \multicolumn{6}{|l|}{ ALL Patients group } \\
\hline \multicolumn{6}{|c|}{$\mathbf{N F} \mathbf{k} \boldsymbol{\beta}$ gen median expression } \\
\hline $0.303^{\text {low\$ }}$ & 14 & 9 & 5 & 64.3 & \multirow[t]{2}{*}{0.678} \\
\hline $0.303^{\text {equal/high\# }}$ & 14 & 10 & 4 & 71.4 & \\
\hline \multicolumn{6}{|c|}{ PIM2 gene median expression } \\
\hline $1.988^{\text {low\$ }}$ & 19 & 11 & 9 & 64.3 & \multirow[t]{2}{*}{0.233} \\
\hline $1.988^{\text {equal/high\# }}$ & 11 & 8 & 3 & 71.4 & \\
\hline
\end{tabular}

${ }^{*} P$ value $<0.05$ is considered significant

${ }^{\$}$ Median level of expression lower than 1.398

\#Median level of expression equal or higher than 1.398 
gene was active in 39 out of a total of 42 ALL samples without subtype restriction [28].

The results regarding the contribution of NF $\kappa \beta$ in leukemogenesis might be related to its role in antiapoptotic genes expression such as the caspase- 8 inhibitor FLIP, the apoptosis inhibitor proteins c-IAP1/2 and $\mathrm{XIAP}$, and the BCL2 family of apoptosis regulators. Moreover, NF- $k \beta$ role in tumorgenesis and leukemia might be related to its role in the induction and maintenance of chronic inflammatory microenvironment. Moreover, the induction of epithelial mesenchymal transition by NF $\kappa \beta$ might facilitate distant metastases [29].

In the course of our study, we found a significant correlation between the expression of PIM2 and NF- $\kappa \beta$ genes in AML patients $(P=0.048)$, which is in accordance with the results of the study conducted by Hadeer et al. [30]. Further on, Katarzyna et al. found that the levels of expression PIM2 and NF- $K \beta$ transcripts were significantly higher in acute leukemia patients compared to the healthy control subjects [17]. The interrelation between PIM2 and NF $\kappa \beta$ was documented in several reports. Hammerman et al. indicated that sustained NF- $\mathrm{k} \beta$ activity is crucial for the ability of PIM2 to serve as an oncogene. They reported that the activation of NF- $\kappa \beta$ gene expression by PIM2 is accomplished through the induction of phosphorylation of the oncogenic serine/threonine kinase Cot, resulting in both enhancement of I $\kappa \beta$ kinase activity and a relocation of NF $\kappa \beta$ from predominantly p50 homo dimers to p50/65 heterodimers [31].

The overall survival of AML patients revealed a significant difference as the cumulative survival at 3 months interval in AML patients was higher in $N F-\kappa \beta$ low expressers compared to high expressers $(P=0.047)$. Although, the overall survival was better in PIM2 gene low expressers in comparison to high expressers, the difference between the two groups was not significant $(P=$ 0.872 ). In contrast, in the univariate analysis conducted by Katarzyna et al., a significant difference in the overall survival was detected between AML patients as regards the PIM2 gene expression level, above and below the median value. However, Kataryzna et al. did not report such a difference with respect to $N F-\kappa \beta$ gene expression [17].

After induction therapy, follow-up of AML patients, revealed a significant elevation in the level of expression of PIM2 gene in patients who failed to achieve complete remission in contrast to patients who achieved complete remission $(P=0.042)$. Furthermore, although the number of AML patients who achieved CR was higher in patients with low expression level of PIM2 gene compared to patients with higher expression level, we did not detect a significant difference between the groups. These results are in accordance, with the results of Kapelelko et al. [32], which indicated that the elevation in the expression level of PIM2 gene in blastic cells was associated with resistance to induction therapy, poor prognosis, and shorter leukemia-free survival in AML patients. In addition, Hadeer et al. [30] revealed that AML patients who did not show a response to induction therapy, had a higher expression of PIM2 and NF- $\kappa \beta$ genes in comparison to patients who showed response to therapy. Moreover, perineural invasion, which is a key mechanism involved in the spread of prostate cancer cells was found to be related to the high expression level of PIM2 gene [33]. Rubenstein et al. observed high expression level of PIM2 gene in recurrent CNS lymphomas refractory to rituximab [34]. These observations could be interpreted by the possibility that high expression of PIM2 and NF- $\kappa \beta$ genes could lower the sensitivity of blast cells to apoptosis and increase their resistance to apoptosis induced by cytotoxic drugs [30]. Moreover, the aberrant expression of $N F-k \beta$ gene might be related to the ability of leukemia cells to evade apoptosis and stimulate proliferation [35].

\section{Conclusion}

The elevated expression of PIM2 and NF- $K \beta$ genes in AML and ALL might indicate their association with the pathogenesis of acute leukemia. The high expression level of PIM2 and NF- $K \beta$ genes might be associated with poor overall survival and failure of response to induction therapy in AML patients only; this might suggest that PIM2 and NF- $\kappa \beta$ genes could be regarded as possible prognostic markers in acute leukemia. Further studies with higher number of patients are recommended to document these observations.

\section{Abbreviations \\ NF K $\beta$ : Nuclear factor kappa beta; IKBs: Inhibitors of kappa beta; CNS: Central nervous system; RT-PCR: Reverse transcriptase polymerase chain reaction; FAB: The French-American-British; AL: Acute leukemia; OS: Overall survival; DFS: Disease-free survival}

\section{Acknowledgements}

The authors sincerely thank the National Cancer Institute for providing the data used in the study

\section{Authors' contributions}

RM and SK designed the study and edited the manuscript. HA carried out the data analysis and interpretation of data. SE and MS drafted the manuscript and revised it. All authors have approved the submitted version of this article

\section{Funding}

There is no body responsible for funding this study

Availability of data and materials

Not applicable

\section{Declarations}

Ethics approval and consent to participate

The study was conducted after the approval of the Institutional Review Board of the National Cancer institute (approval date 3 March 2015; approval no. 2010014035.3), which conforms with the Code of Ethics of the World 
Medical Association (Declaration of Helsinki), printed in the British Medical Journal (18 July 1964).

We described the aim of this research to subjects' parents or responsible relative shared in this research before enrollment and they gave written consent but refuse to write consent, and ethics committee approved this procedure.

\section{Consent for publication}

Not applicable

\section{Competing interests}

The authors do not have any conflict of interest

\section{Author details}

${ }^{1}$ Clinical and Chemical Pathology Department, Faculty of Medicine, Beni-Suef University, Beni-Suef 62511, Egypt. ${ }^{2}$ Department of Medical Oncology, National Cancer Institute, Faculty of Medicine, Cairo University, Cairo, Egypt. ${ }^{3}$ Department of Internal Medicine, Faculty of Medicine, Cairo University, Cairo, Egypt.

\section{Received: 2 November 2020 Accepted: 24 March 2021}

Published online: 17 May 2021

\section{References}

1. Wang M, Zhang C, Tian T (2018) Increased regulatory T cells in peripheral blood of acute myeloid leukemia patients rely on tumor necrosis factor (TNF) alpha-TNF receptor-2 pathway. Front Immunol 9:1274. https://doi. org/10.3389/fimmu.2018.01274

2. Estey E, Gale R, Sekeres M. (2018) New drug approvals in acute myeloid leukemia: uses and abuses. Leukemia. Jun 6. https://doi.org/10.1038/s41375018-0168-z In press.Ther Adv Hematol.,1 : 1

3. Chiaretti S, Carobolante F, Skert C, Bassan R (2014) Practical guidance for the management of acute lymphoblastic leukemia in the adolescent and young adult population. Ther Adv Hematol 11:1-25

4. Zhang X, Song M, Kumar MH, Lee J, Lou ZZ (2018) PIM kinase as an executional target in cancer. J Cancer Prev 23(3):109-116. https://doi.org/1 0.15430/JCP.2018.23.3.109

5. Photini M, Chaiwangyen W, Weber M, Al-Kawlani B, Favaro RR, Jeschke U, EDM S, Morales-Prieto DM, Markert UR (2017) PIM kinases 1, 2 and 3 in intracellular LIF signaling, proliferation and apoptosis in trophoblastic cells. Experimental cell research 359(1):275-283. https://doi.org/10.1016/j.yexcr.201 7.07.019

6. Liu ZT, Mengyue DK, Liu H, Wang Y, Rong F (2019) High expression of PIM2 induces HSC proliferation in myelodysplastic syndromes viathe IDH1/HIF1-a signaling pathway. Oncol Letters 17:5395-5402

7. Bullock AN, Russo S A, Amos A, Pagano, N, Bergman H, Debreczeni JE. (2009) Crystal structure of the PIM2 kinase in complex with an organoruthonium inhibitor. PLoS One: 4: e7112. 10 1371/journal.pone. 0007112.

8. Wang W, Mani AM, Wu ZH (2017) DNA damage-induced nuclear factorkappa B activation and its roles in cancer progression. Cancer Meta Treat 3: 45-59

9. Munugalavadla V (2011) A critical role for PIM2 kinase in multiple nylons through NF-kB activation. Blood 118(21):1839-1839. https://doi.org/10.1182/ blood.V118.21.1839.1839

10. Dzneladze I., .He R., Woodley JF. , Son MH., Sharobim MH., Greenberg SA. Gabra M. , Langlois C., Rashid A. , Hakem A. , Ibrahimova N., Arruda A. Lowenberg B., Ball PJM., MindenMD. and Salmena L. (2015) INPP4B overexpression is associated with poor clinical outcome and therapy resistance in acute myeloid leukemia. Leukemia $29: 1485,7$, 1495, DOl: https://doi.org/10.1038/leu.2015.51

11. Burnett A.K., Venditti A. (2011), Acute myeloid leukemia. In: Postgraduate hematology, 6th edn. Hoffbrand AV, Catovsky D, Tuddenham ED, Green AR (eds) ,Wiley-Blackwell, 415.

12. Campania D. and Pui C.H. (2011) Childhood acute lymphoblastic leukemia In: Postgraduate hematology, 6th edn. Hoffbrand AV, Catovsky D, Tuddenham ED, Green AR (eds) Wiley-Blackwell , 448-62.

13. Tallman MS (2005) New strategies for the treatment of acute myeloid leukemia including antibodies and other novel agents. Hematol Am Soc Hematol Educ Program 1:143-150
14. Francesca C., Sabina C., Cristina S. and .Renato B. (2020) Practical guidance for the management of acute lymphoblastic leukemia in the adolescent and young adult population, The Adv. Hematol., 11, 204062072090353, doi: https://doi.org/10.1177/2040620720903531

15. Beillard F., Pallisgaard N., van der Velden VHJ, .Bi W. , .Dee R., van der Schoot E, Delabesse E, Macintyre E, Gottardi E, Saglio G, Watzinger F, Lion T, van Dongen JJ, Hokland P, and Gabert J. (2003) Evaluation of candidate control genes for diagnosis and residual disease detection in leukemic patients using 'real-time' quantitative reverse-trans-criptase polymerase chain reaction (RQ-PCR) - a Europe against cancer program. Leukemia; 17: 2474, 12, 2486, DOI: https:// doi.org/10.1038/sj.leu.2403136

16. Kuhnl A. , Gukbuget N., Kaiser M., Schlee C., Stroux A., Burmeister T. ,Mochmann LH. , Hoelzer D., Hofmann WK. , Thiel E. and Baldus Cd., (2011) Over expression of LEF1 predicts unfavorable outcome in adult patients with B-precursor acute lymphoblastic leukemia. Blood, 118(24): 6362, 6367, DOI: https://doi.org/10.1182/blood-2011-04-350850.

17. Kataryzna KS, Urbaniak-Kujda D, Wołowiec D, Jaźwiec B, Dybko J, Jakubaszko J, Słowik M, Kuliczkowski K (2013) Expression of PIM-2 and $N F-K B$ genes is increased in patients with acute myeloid leukemia (AML) and acute lymphoblastic leukemia (ALL) and is associated with complete remission rate and overall survival. Postepy Hig Med Dosw (Online) 67:553

18. Jang SH, Chung HY (2012) MYC and PIM2 coexpression in mouse bone marrow cells readily establishes permanent myeloid cell lines that can induce lethal myeloid sarcoma in vivo. Mol Cells 34:201-208. https://doi. org/10.1007/s10059-012-0142-y

19. Aggarwal B, Sung B (2011) NF-kappa B in cancer: a matter of life and death. Cancer Discov 1(6):469

20. Ramachandran J., SantoL., Siu KT., Panaroni C., Raje N. (2016) Pim2 is important for regulating DNA damage response in multiple myeloma cells. Blood Cancer J ;6: e462, 8, DOl: https://doi.org/10.1038/bcj.2016.73.

21. Mizuki M, Schwable J, Steur C, Choudhary C, Agrawal S, Sargin B, Steffen B, Matsumura I (2003) Suppression of myeloid transcription factors and induction of STAT response genes by AML- specific. Flt3 mutations. Blood 101(8):3164-3173. https://doi.org/10.1182/blood-2002-06-1677

22. Tmburini J., Green A., Bardet V., Chapuis N., Park S., and, Willems L. (2009) Protein synthesis is resistant to rapamycin and constitutes a promising therapeutic target in acute myeloid leukemia. Blood, 114(8) :1618-1627, DOI: https://doi.org/10.1182/blood-2008-10-184515.

23. Gomez-Abad C, Pisonero H, Blanco-Aparicio C, Roncador G, GonzalezMenchen A, Martinez-Climent J (2011) PIM2 inhibition as a rational therapeutic approach in B-cell lymphoma. Blood 118(20):5517-5527. https:// doi.org/10.1182/blood-2011-03-344374

24. Patrizia M, Salvatore C, Michael M (2014) PIM 2 kinases in hematological malignancies: where are we now and where are we going? Journal of Hematology \&amp. Oncology 7:95

25. Liu K, Gao H, Wang Q, Wang L, Zhang B, Han Z (2018) Hispidulin suppresses cell growth and metastasis by targeting PIM1 through JAK2/STAT3 signaling in colorectal. Cancer 109:1369-1381

26. Kapleko-Slowik K, Urabaniak-Kujda D, Wolowiec D, Dybko J, Slowik M, Potoczek K, Kuliczkowski S (2010) Expression in acute myeloid leukemia and acute lymphoblastic leukemia patients and complete remission. Adv Clin Exp Med 19:299

27. Amanda L, Albert S (2016) The NFk $\beta$ pathway and cancer stem cells. Cells $5(2): 16$

28. Kordes U., Kappermann D., Heissmeyer V., Ludwig WD.and Scheidereit C. (2000), Transcriptional factor NF $\mathrm{k} \beta$ is constitvely activated in acute lymphoblastic leukemia cells, 14: 399.

29. Xia Y, Shen S, and Inder MV. (2014) NF-KB, an active player in human, 2 (9) : 823-830.

30. Hadeer AA, Hanaa MD, Omar MG (2016) Association of PIM-2 and NF-KB overexpression with poor clinical outcome in Egyptian patients with acute myeloid leukemia. Int J Curr Res 8(07):34399

31. Hammerman PS, Fox CJ, Cinalli RM, Xu A, Wagner JD, Lindsten T, Thompson C (2004) Lymphocyte transformation by PIM2 is dependent on nuclear factor-kappa B activation. Cancer Res 64(22):8341-8348. https://doi.org/10.11 58/0008-5472.CAN-04-2284

32. Kapelko-Slowik K., .Owczarek T. , Grzymajlo K., UrbaniakKujda D., Jazwiec B. and Slowik M (2016) Elevated PIM2 gene expression is associated with poor survival of patients with acute myeloid leukemia. Leuk Lymphoma, 13: 1. 
33. Ayala G., .Dai H., Ittmann M. ,. Li R., Well M A, Frolov A. et al., (2004) Growth and survival mechanisms associated with perineural invasion in prostate cancer. Cancer Res., 64 (17) : ,6082-6090, DOl: https://doi.org/10.1158/00085472.CAN-04-0838.

34. Rubenstein J., .Li J., Chen L. , Advani R., Drappatz J. and E.Gerstner E.(2013) Multicenter phase 1 trial of intraventricular immunochemotherapy in recurrent CNS lymphoma. Blood, 121(5) :745-751, DOl: https://doi.org/10.11 82/blood-2012-07-440974.

35. Zhou J., .Ching Y. and Chng W. (2015) Aberrant nuclear factor kappa B activity in acute myeloid leukemia: from molecular pathogenesis to therapeutic target. Oncotarget, 6 (8) :5490-5500, DOI: https://doi.org/10.1 8632/oncotarget.3545

\section{Publisher's Note}

Springer Nature remains neutral with regard to jurisdictional claims in published maps and institutional affiliations.

\section{Submit your manuscript to a SpringerOpen ${ }^{\circ}$} journal and benefit from:

- Convenient online submission

- Rigorous peer review

- Open access: articles freely available online

High visibility within the field

- Retaining the copyright to your article

Submit your next manuscript at $\boldsymbol{\nabla}$ springeropen.com 